\title{
VARIASI GENETIK TIGA GENERASI IKAN HIAS CUPANG ALAM ENDEMIK DARI ACEH Betta rubra, Perugia 1893 (Pisces: Osphronemidae), HASIL BUDIDAYA
}

\author{
Erma Primanita Hayuningtyas", Eni Kusrini, Shofihar Sinansari, dan Melta Rini Fahmi \\ Balai Riset Budidaya Ikan Hias \\ Jl. Perikanan No. 13, Pancoran Mas, Depok 16436
}

(Naskah diterima: 5 November 2019; Revisi final: 7 April 2021; Disetujui publikasi: 7 April 2021)

\begin{abstract}
ABSTRAK
Betta rubra merupakan salah satu spesies ikan cupang alam endemik dari Aceh. Keberadaannya yang hampir dinyatakan punah sebelum ditemukan kembali pada tahun 2007. Tujuan dari penelitian ini adalah mengkaji keragaman genetik dan potensi genetik dari ikan Betta rubra dari tiga generasi yang sudah dibudidayakan untuk perbaikan genetik di Balai Riset Budidaya Ikan Hias (BRBIH), Depok, Jawa Barat, Indonesia. Jumlah sampel yang digunakan pada populasi G-0 adalah enam ekor, sedangkan pada populasi G-1 dan G-2 masing-masing 10 ekor. Ikan uji yang digunakan diambil sirip ekornya untuk analisis secara genotipe dengan randomly amplified polymorphic DNA (RAPD) menggunakan primer yaitu OPZ-9, OPB-6, dan OPZ-13. Sebelum diambil sirip ekornya ikan terlebih dahulu difoto di atas millimeter block untuk data truss morfometrik (fenotipe). Hasil menunjukkan ikan Betta rubra populasi alam (G-0) memiliki nilai heterozigositas 0,1872 dan derajat polimorfisme $47,06 \%$ yang lebih rendah dibandingkan generasi G-1 dengan heterozigositas 2,421 dan derajat polimorfisme $64,71 \%$ Populasi G-2 memiliki nilai heterozigositas 0,1577 dan derajat polimorfisme $44,12 \%$ Koefisien keragaman secara fenotipe populasi G-1 memiliki variasi lebih tinggi dibanding populasi G-0 dan G-2. Hubungan kekerabatan antara G-1 dengan G-0 dan G-2 berbeda nyata $(P<0,05)$, sedangkan hubungan antara $G-1$ dengan $G-2$ tidak berbeda nyata $(P>0,05)$, sehingga antara populasi G-0 dan G-2 membentuk cluster terpisah dengan G-1. Keragaman genetik pada tiga generasi Betta rubra memiliki pola yang sama baik secara fenotipe maupun genotipe.
\end{abstract}

KATA KUNCl: Betta rubra; keragaman genetik; RAPD; truss morfometrik

ABSTRACT: Genetic variation of three farmed-generations of Betta rubra, Perugia 1893 (Pisces: Osphronemidae), an endemic fish to Aceh. By: Erma Primanita Hayuningtyas, Eni Kusrini, Shofihar Sinansari, and Melta Rini Fahmi

Betta rubrais one of the endemic species of Betta fish from Aceh. The fish was almost declared extinct beforeit was rediscovered in 2007. The purpose of this study was to examine the genetic diversity and genetic potential of Betta rubra from three generations which have been reared for genetic improvement at the Research Institute for Ornamental Fish Culture, Depok, West Java, Indonesia. The number of fish for G-0 population used in the study was six fish whilst G-1 and G-2 populations were 10 fish. Tail fins from each fish were sampled for genotype analysis using randomly amplified polymorphic DNA (RAPD) using primers OPZ-9, OPB-6, and OPZ-13. Before tail fin collection, the fish was photographed on a millimeter block for truss morphometric data measurement (phenotype). The results showed that the Betta rubra wild population (G-0) had heterozygosity of 0.1872 and polymorphism of $47.06 \%$ which were lower than the G-1 population with heterozygosity of 2.421 and polymorphism of $64.71 \%$ The G-2 population had heterozygosity of 0.1577 and polymorphism of $44.12 \%$ The phenotype coefficient of variation in the G-1 population higher than the G-0 and G-2 populations. The kinship relationship between G-1 with G-0 and G-2 was significantly different $(P<0.05)$, while the relationship between $G-1$ and $G-2$ was not significantly different $(P>0.05)$. This research concludes that the populations of G-0 and G-2 have formed a separate cluster to G-1. The genetic diversities in the three Betta rubra populations have similar phenotype and genotype patterns.

KEYWORDS: Betta rubra; genetic diversity; RAPD; truss morphometric

\footnotetext{
\# Korespondensi: Balai Riset Budidaya Ikan Hias

Jl. Perikanan No. 13, Pancoran Mas, Depok 16436, Indonesia

E-mail: erma_primanita@yahoo.com
} 


\section{PENDAHULUAN}

Ikan cupang alam yang berasal dari perairan Indonesia terdiri atas 51 spesies yang tergolong berkembang biak dengan membuat sarang busa (bubblenester) dan berkembang biak dengan mengerami telur dan larvanya dalam mulut (mouthbrooder). Salah satu jenis cupang alam yang menarik perhatian adalah Betta Rubra atau "Toba Betta". Spesies ini endemik di perairan Banda Aceh dan sekitarnya. Ikan ini mulai populer sejak 2007 karena merupakan jenis langka.

Sebagai ikan cupang alam endemik Sumatera, keberadaannyaikan Betta rubra yang dinyatakan hampir punah. Namun ikan ini, corak merah dan coklat, ditemukan kembali pada tahun 2007 di daerah Meulaboh dan Aceh Barat (Schindler \& Voort, 2011). Betta rubra memiliki beberapa macam corak, untuk corak tiger (merah hitam) ditemukan di Banda Aceh pada September 2009. Kini, ikan cupang langka ini telah dikembangbiakkan oleh Aceh Betta Farm.

Kini, ikan cupang langka ini telah dikembangbiakkan oleh Aceh Betta Farm. Jenis cupang ini sangat diminati dan diburu oleh para penggemar ikan cupang alam, berkualitas ekspor, dan memiliki harga cukup tinggi Rp450.000,00 (Jitunews, 2015). Keberadaan ikan B. rubra di daerah asal sulit ditemukan sedangkan budidayanya belum berkembang. Oleh karena itu, konservasi ikan Betta rubra harus segera dilakukan.

Kegiatan budidaya Betta rubra telah dilakukan di Balai Riset Budidaya Ikan Hias sejak tahun 2017. Hingga kini telah dihasilkan dua generasi dari indukan yang berasal dari alam. Untuk melihat performa genetik dari Betta rubra hasil budidaya perlu dianalisis keragaman dan kekerabatannya. Analisis keragaman genetik dapat dilakukan secara fenotipe dan genotipe. Salah satu analisis fenotipe yang dapat dilakukan adalah dengan pengukuran truss morfometrik. Pengukuran karakter truss morfometrik sebelumnya pernah dilakukkan pada ikan kemprit (llisha megalopteran Swainson, 1839) (Wijayanti et al., 2017), ikan gabus (Kusmini et al., 2015), ikan gurame (Arifin et al., 2017), ikan nila (Ariyanto et al., 2011), ikan mas (Cahyanti et al., 2014), dan ikan kelabau (Asiah et al., 2018).

Analisis karakter genotipe dapat dilakukan dengan berbagai metode molekular seperti RFLP, mikrosatelit, RAPD, dan DNA barcoding. RAPD atau randomly amplified polymorphic DNA merupakan salah satu metode molekular yang menggunakan single primer dengan 10 basa nucleotida. Metode RAPD merupakan metode yang sering digunakan untuk karakterisasi berbagai spesies ikan di antaranya karakterisasi populasi ikan tengadak (Kusmini et al., 2016), variasi genetik ikan baronang (Lante et al., 2012), keragaman genetik empat populasi ikan rajadanu (Cahyanti et al., 2014), variasi genetik ikan tambakan (Kristanto et al., 2017), karakter genotipe ikan Rainbow ajamaru (Hayuningtyas et al., 2018), keragaman genetik ikan Belida (Nugroho et al., 2019) dan masih banyak penelitian lainnya terkait keragaman genetik. Keragaman genetik dideteksi menggunakan RAPD dilakukan untuk melihat tingkat polimorfisme, heterozigositas, serta hubungan kekerabatan yang terjadi secara inter maupun intra-populasi. Analisis secara fenotipe dan genotipe pada tiga generasi Betta rubra diharapkan dapat menjadi solusi untuk melihat genetic drift yang terjadi dari tiap generasi. Tujuan dari penelitian ini adalah mengkaji variasi genetik dan potensi genetik ikan Betta rubra dari tiga generasi yang sudah dibudidayakan untuk perbaikan genetiknya.

\section{BAHAN DAN METODE}

Ikan uji yang digunakan adalah ikan Betta rubra dari dua generasi hasil budidaya. Pada awalnya ikan yang dikoleksi dari alam berjumlah 16 ekor kemudian dipijahkan secara alami dengan memasukan lima pasang ikan B. rubra dalam styroform berukuran 50 $\mathrm{cm} \times 60 \mathrm{~cm} \times 30 \mathrm{~cm}$ dan diberi pipa sepanjang $10 \mathrm{~cm}$ dengan diameter $3 \mathrm{~cm}$ yang digunakan sebagai selter untuk memijah. Karena pemijahan pada ikan B. rubra bersifat mouthbrooder sehingga larva yang dihasilkan atau dipanen dari satu induk jantan adalah berasal dari sepasang induk jantan dan betina meskipun pada saat menjodohkan terdapat beberapa pasang dalam wadah pemijahan. Jumlah sampel yang digunakan untuk anal isis genotipe adalah ikan B. rubra G-0 hasil koleksi dari alam sebanyak enam ekor (karena pada saat pengambilan sampel ikan yang tersisa hanya tinggal enam ekor) dan untuk sampel G-1 dan G-2 masingmasing sebanyak 10 ekor. Setiap individu diambil sampel organ sirip ekor untuk di ekstraksi DNA.

\section{Ekstraksi DNA}

Organ sirip yang sudah diambil selanjutnya diekstraksi DNA dengan menggunakan prosedur gSYNC DNA Extraction Kit Quick Protocol (Genaid, Taiwan). Sirip ikan B. rubra sebanyak 10-25 mg dihancurkan, kemudian ditambahkan larutan lysis atau penghancur, diinkubasi hingga larut, selanjutnya dipisahkan dari RNA, protein, dan kontaminan lainnya melalui proses sentrifugasi, dilakukan pula penambahan wash buffer dan alkohol untuk penyempurnaan proses pencucian DNA agar bebas dari kontaminan. Terakhir ditambahkan elution buffer atau nuclease free water untuk menghasilkan genom DNA yang murni.

Amplifikasi polymerase chain reaction (PCR) dengan metode RAPD. RAPD atau Randomly ampli- 


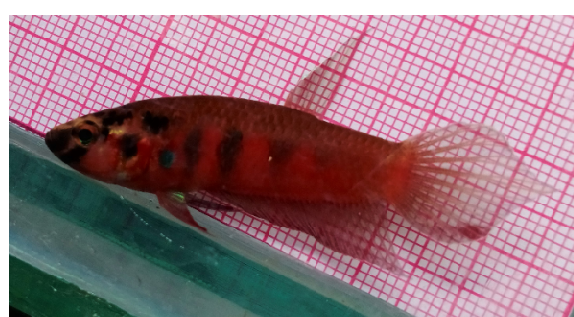

(a)

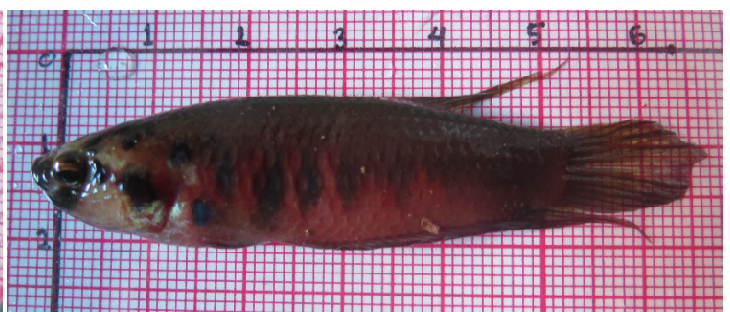

(b)

Gambar 1. Ikan Betta rubra G-0 (a) jantan dan (b) betina.

Figure 1. G-0 Betta rubra fish (a) male and (b) female.

fied polymorphic DNA adalah metode PCR yang menggunakan single primer yang menempel secara random. Sehingga perlu dilakukan tahapan screening terhadap beberapa primer yang digunakan. Pada penelitian ini ada enam jenis primer yang akan di screening Tabel 1. PCR dilakukan menggunakan thermocycler gradient $(A B)$ agar suhu annealing bisa diatur sesuai dengan TM dari masing-masing primer. Program PCR terdiri atas denaturasi awal pada suhu $94^{\circ} \mathrm{C}$ selama dua menit, 35 siklus terdiri atas denaturasi $94^{\circ} \mathrm{C}$ selama satu menit, annealing sesuai temperature melting primer selama satu menit, dan extension $72^{\circ} \mathrm{C}$ selama dua menit, dan diakhiri dengan satu siklus ekstension pada $72^{\circ} \mathrm{C}$ selama tujuh menit. Komposisi pereaksi terdiri atas $12,5 \mu \mathrm{L}$ Dream taq Master Mix 2x (Thermo Scientific), $1 \mu \mathrm{L}$ primer RAPD, $3 \mu \mathrm{L}$ DNA, dan ditambah nuclease free water sampai total volume $25 \mu \mathrm{L}$.

\section{Elektroforesis dan Visualisasi}

Produk PCR yang dihasilkan selanjutnya masingmasing dimasukkan ke dalam sumur gel (well) sebanyak $6 \mu \mathrm{L}$ (sudah mengandung dye) pada gel agarose $1,5 \%$ yang mengandung pewarna gel $0,01 \%$ (PeqGreen). Elektroforesis dilakukan bersama marker 100 bp Plus (Vivantis) pada voltase 100 volt selama 60 menit pada media 1x TBE (Tris Borate EDTA) menggunakan PowerPac Basic (Bio-Rad). Selanjutnya visualisasi DNA dilakukan menggunakan Gel documentation - UV transiluminator Alphalmager
(ProteinSimple). Kemunculan fragmen DNA diubah ke dalam bentuk data biner untuk dapat dianalisis menggunakan software.

\section{Karakterisasi Fenotipe Truss Morfometrik}

Ikan cupang Betta rubra difoto terlebih dahulu di atas millimeter block secara tegak lurus dengan kepala menghadap sebelah kiri, sebelum siripnya dipotong untuk analisis genotipe. Foto ikan selanjutnya diukur menggunakan software Image Raster 3.0 dengan pengukuran 21 karakter truss morfometrik sesuai pada Gambar 2 dan deskripsi dari tiap karakter dijabarkan pada Tabel 2. Data dari hasil pengukuran morfometrik dikonversi ke dalam rasio antara setiap pengukuran dibagi dengan panjang standar.

\section{Analisis Data}

Karakter genotipe yang diukur adalah keragaman genetik dan uji perbandingan Fst berpasangan menggunakan tools for population genetic analisis (TFPGA). Hubungan kekerabatan antar populasi dianalisis berdasarkan jarak genetik dengan unweighted pair methods with arithmetic average (UPGMA) dan disajikan dalam bentuk dendogram. Karakter fenotipe dianalisis menggunakan analisis pengelompokkan (Cluster Analysis) untuk mengevaluasi keragaman intra-populasi dan inter-populasi ikan cupang Betta rubra. Analisis keragaman morfometrik antar populasi dilakukan secara deskriptif dengan membandingkan coefficient of variation (CV).

Tabel 1. Jenis primer RAPD yang digunakan untuk screening

Table 1. RAPD primer types used for screening

\begin{tabular}{lcccc}
\hline $\begin{array}{l}\text { Kode primer } \\
\text { Primers code }\end{array}$ & $\begin{array}{c}\text { Urutan basa (5'- } \\
\left.\mathbf{3}^{\prime}\right)\end{array}$ & $\begin{array}{c}\text { Panjang } \\
\text { nukleotida }\end{array}$ & G+ C (\%) & $\begin{array}{c}\text { Titik didih } \\
\text { Temperature melting }\end{array}$ \\
\hline OPB-06 & TGCTCTGCCC & 10-mer & 70 & 39.8 \\
OPA-03 & AGTCAGCCAC & $10-$ mer & 60 & 34.3 \\
OPA-18 & AGGTGACCGT & $10-\mathrm{mer}$ & 60 & 36.2 \\
OPZ-5 & GGCTGCGACA & $10-\mathrm{mer}$ & 70 & 41.2 \\
OPZ-9 & AGCAGCGCAC & $10-\mathrm{mer}$ & 70 & 42.5 \\
OPZ-3 & GGGTCTCGGT & $10-\mathrm{mer}$ & 70 & 38.0 \\
\hline
\end{tabular}




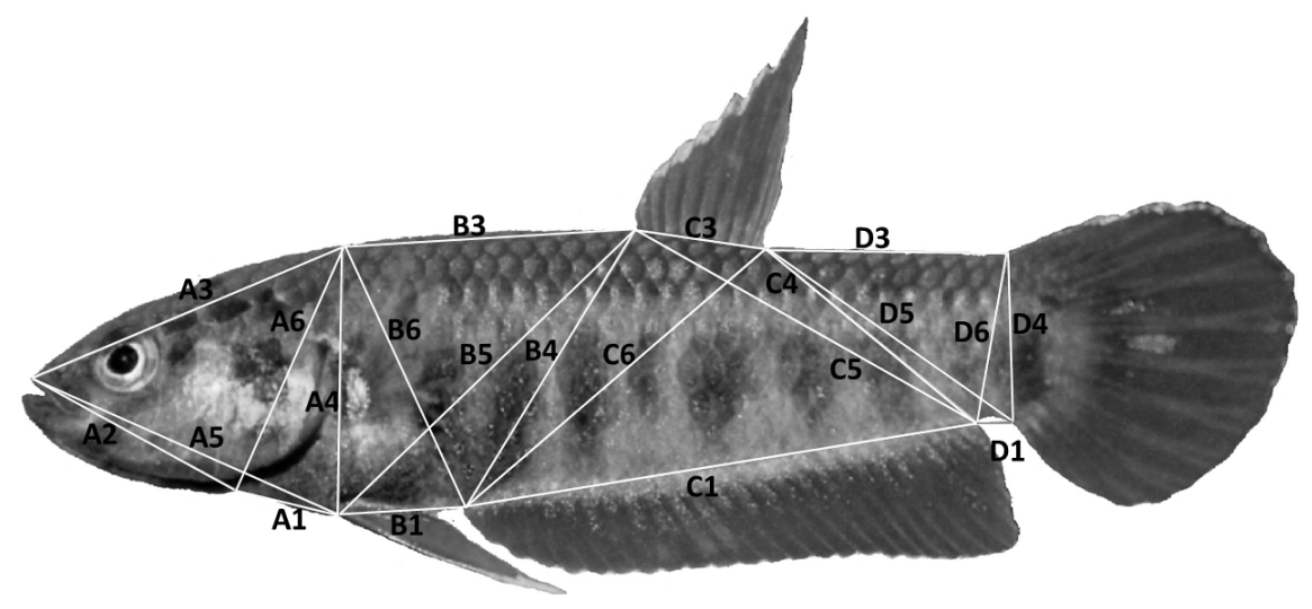

Gambar 2. Pengukuran karakter truss morfometrik dari ikan cupang Betta rubra (Brezky \& Doyle, 1988 dengan modifikasi).

Figure 2. Measurement of truss morfometric character of Betta rubra (Brezky \& Doyle, 1988 with some modifications).

\section{HASIL DAN BAHASAN}

Gambar 3 merupakan hasil screening primer dengan menggunakan sampel ikan Betta rubra G-0 dan enam primer RAPD yaitu OPZ-5, OPA-3, OPB-6, OPZ-9, OPA18, dan OPZ-13. Hasil screening primer menunjukkan tiga primer yang polimorfik dan konsisten adalah OPB6, OPZ-9, dan OPZ-13. Sehingga PCR RAPD pada seluruh sampel dilanjutkan dengan menggunakan tiga primer tersebut. Pada populasi G-0 indukan yang tersisa hanya enam ekor sehingga hanya dilakukan pengambilan sampel dari induk yang ada. Pada ikan Betta rubra G-1 dan G-2 jumlah sampel yang digunakan masing-masing 10 sampel.

Gambar 4 menunjukkan hasil amplifikasi DNA menggunakan primer OPB-6. Terdapat lokus yang muncul dominan yaitu pada ukuran 800 bp. Pada Gambar 5 menunjukkan hasil amplifikasi DNA menggunakan primer OPZ-9 dan lokus yang dominan lebih banyak yaitu pada ukuran 600 bp, 700 bp, 800 bp, dan 1.500 bp. Hasil amplifikasi DNA dengan menggunakan primer OPZ-13 menghasilkan lebih banyak kemunculan fragmen dan lokus yang dominan pun lebih banyak yaitu pada $450 \mathrm{bp}, 700 \mathrm{bp}, 850 \mathrm{bp}$, 950 bp, 1.200 bp, 1.300 bp, 1.600 bp, dan 1.900 bp (Gambar 6). Pada amplifikasi menggunakan primer OPZ-13 fragmen yang dihasilkan lebih banyak dibandingkan dengan menggunakan primer lainnya. Hasil kemunculan fragmen dan ukuran fragmen dengan menggunakan tiga primer ditampilkan pada Tabel 3 dan Tabel 4.

Berdasarkan kemunculan fragmen, kisaran jumlah fragmen yang muncul maupun ukuran fragmen yang muncul ditampilkan pada Tabel 3 dan 4. Kemunculan fragmen berdasarkan penggunaan primer OPZ-9 menghasilkan 10 lokus dengan kisaran jumlah yang muncul 2-9 fragmen dan kisaran ukuran 500-2.800 bp. $\mathrm{Hal}$ ini menunjukkan bahwa variasi kemunculan fragmen tertinggi ada pada polulasi G-2, dan yang terendah adalah pada populasi G-0.

Kemunculan fragmen menggunakan OPB-6 menghasilkan 11 lokus dengan kisaran jumlah fragmen yang muncul 1-9 fragmen dan kisaran ukuran 300-2.000 bp. Hal ini menunjukkan variasi kemunculan fragmen tertinggi adalah pada populasi G-1, sementara yang terendah adalah pada populasi G-0.

Kemunculan fragmen menggunakan OPZ-13 menghasilkan 13 lokus dengan kisaran jumlah fragmen yang muncul 3-10 dan kisaran ukuran 400-2.600 bp. Hal ini menunjukkan variasi kemunculan fragmen tertinggi adalah pada populasi G-0 dan terendah adalah pada populasi G-2. Kemunculan fragmen pada populasi ikan Betta rubra memiliki variasi yang cukup tinggi yaitu 300-2.800. Menurut Hayuningtyas et. al. (2018), kemunculan fragmen pada ikan hias rainbow ajamaru memiliki variasi yang tinggi yaitu dengan berat molekul 300-3.000 bp dan jumlah fragen yang tinggi juga 1-13 fragmen. Pola kemunculan fragmen yang berbeda tergantung dari tiap individu dan jenis primer yang digunakan.

Nilai heterozigositas dan polimorfisme yang dihasilkan dari ketiga populasi ikan Betta rubra ditampilkan pada Tabel 2. Nilai heterozigositas tertinggi adalah pada populasi G-1 $(0,2421)$ dan terendah adalah pada populasi G-2 $(0,1577)$. Nilai 
Tabel 2. Deskripsi 21 karakter truss morfometrik ikan cupang Betta rubra

Table 2. Description of 21 truss morphometric characters of Betta rubra

\begin{tabular}{|c|c|c|}
\hline Bidang truss(Area truss) & Kode (Code) & Deskripsi jarak (Description of distance) \\
\hline \multirow{6}{*}{$\begin{array}{l}\text { Kepala } \\
\text { Head }\end{array}$} & $\mathrm{A} 1$ & $\begin{array}{l}\text { Ujung bawah operculum-awal sirip perut } \\
\text { Lower end of operculum-beginning of pelvic fins }\end{array}$ \\
\hline & A2 & $\begin{array}{l}\text { Ujung mulut bagian atas-ujung bawah operculum } \\
\text { Upper end of mouth-the lower end of operculum }\end{array}$ \\
\hline & A3 & $\begin{array}{l}\text { Ujung mulut bagian atas-bagian akhir tulang kepala } \\
\text { Upper end of mouth-latter part of skull }\end{array}$ \\
\hline & A4 & $\begin{array}{l}\text { Bagian akhir tulang kepala-awal sirip perut } \\
\text { Latter part of skull - beginning of pelvic fins }\end{array}$ \\
\hline & A5 & $\begin{array}{l}\text { Ujung mulut bagian atas-awal sirip perut } \\
\text { Upper end of mouth-beginning of pelvic fins }\end{array}$ \\
\hline & A6 & $\begin{array}{l}\text { Ujung bawah operculum-bagian akhir tulang kepala } \\
\text { Lower end of operculum-latter part of skull }\end{array}$ \\
\hline \multirow{5}{*}{$\begin{array}{l}\text { Badan tengah } \\
\text { Midsection }\end{array}$} & B1 & $\begin{array}{l}\text { Awal sirip perut-awal sirip anal } \\
\text { Beginning of pelvic fin-the beginning of the anal fin }\end{array}$ \\
\hline & B3 & $\begin{array}{l}\text { Bagian akhir tulang kepala-awal sirip punggung } \\
\text { Latter part of skull-beginning of dorsal fin }\end{array}$ \\
\hline & B4 & $\begin{array}{l}\text { Awal sirip punggung-awal sirip anal } \\
\text { Beginning of dorsal fin-beginning of anal fin }\end{array}$ \\
\hline & B5 & $\begin{array}{l}\text { Bagian akhir tulang kepala-awal sirip anal } \\
\text { Latter part of skull-beginning of anal fin }\end{array}$ \\
\hline & B6 & $\begin{array}{l}\text { Awal sirip perut-awal sirip punggung } \\
\text { Beginning of pelvic fin-beginning of dorsal fin }\end{array}$ \\
\hline \multirow{5}{*}{$\begin{array}{l}\text { Badan belakang } \\
\text { Rear body }\end{array}$} & $\mathrm{Cl}$ & $\begin{array}{l}\text { Awal sirip anal-akhir sirip anal } \\
\text { Beginning of anal fin-end of anal fin }\end{array}$ \\
\hline & C3 & $\begin{array}{l}\text { Awal sirip punggung-akhir sirip punggung } \\
\text { Beginning of dorsal fin-end of dorsal fin }\end{array}$ \\
\hline & C4 & $\begin{array}{l}\text { Akhir sirip punggung-akhir sirip anal } \\
\text { End of dorsal fin-end of anal fin }\end{array}$ \\
\hline & C5 & $\begin{array}{l}\text { Awal sirip punggung-akhir sirip anal } \\
\text { Beginning of dorsal fin-end of anal fin }\end{array}$ \\
\hline & C6 & $\begin{array}{l}\text { Awal sirip anal-akhir sirip punggung } \\
\text { Beginning of anal fin-end of dorsal fin }\end{array}$ \\
\hline \multirow{5}{*}{$\begin{array}{l}\text { Pangkal ekor } \\
\text { Caudal peduncle }\end{array}$} & D1 & $\begin{array}{l}\text { Akhir sirip anal-awal sirip ekor bawah } \\
\text { End of anal fin-beginning of lower part of caudal fin }\end{array}$ \\
\hline & D3 & $\begin{array}{l}\text { Akhir sirip punggung-awal sirip ekor atas } \\
\text { End of dorsal fin-beginning of upper part of caudal fin }\end{array}$ \\
\hline & D4 & $\begin{array}{l}\text { Awal sirip ekor atas-awal sirip ekor bawah } \\
\text { Beginning of upper part of caudal fin-beginning of lower part of caudal fin }\end{array}$ \\
\hline & D5 & $\begin{array}{l}\text { Akhir sirip punggung-awal sirip ekor bawah } \\
\text { End of dorsal fin-beginning of lower part of caudal fin }\end{array}$ \\
\hline & D6 & $\begin{array}{l}\text { Akhir sirip anal-awal sirip ekor atas } \\
\text { End of anal fin-beginning of upper part of caudal fin }\end{array}$ \\
\hline
\end{tabular}




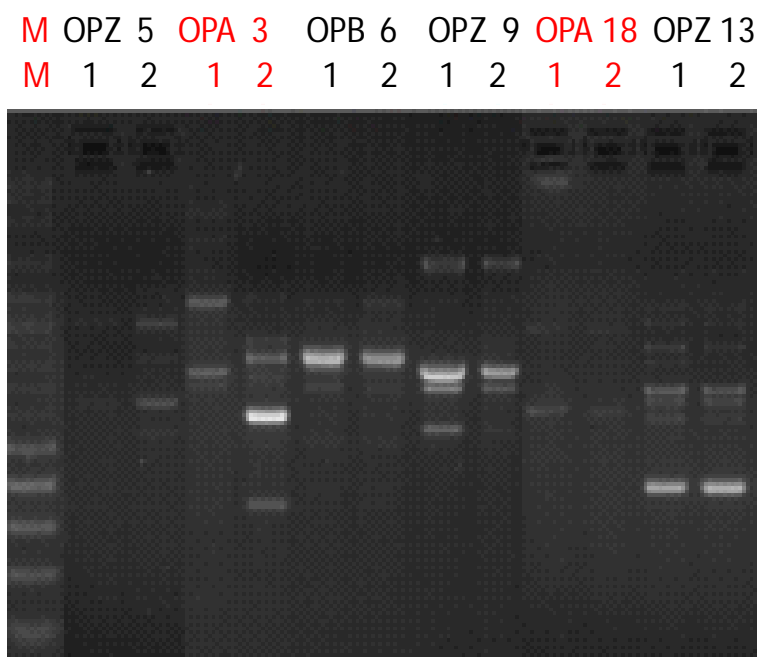

Gambar 3. Hasil screening primer RAPD pada populasi ikan Betta rubra menggunakan primer OPZ-5, OPA-3, OPB-6, OPZ-9, OPA-18, OPZ-13.

Figure 3. Screening results of RAPD primers of the Betta rubra populations using primers OPZ-5, OPA-3, OPB-6, OPZ-9, OPA-18, OPZ-13.

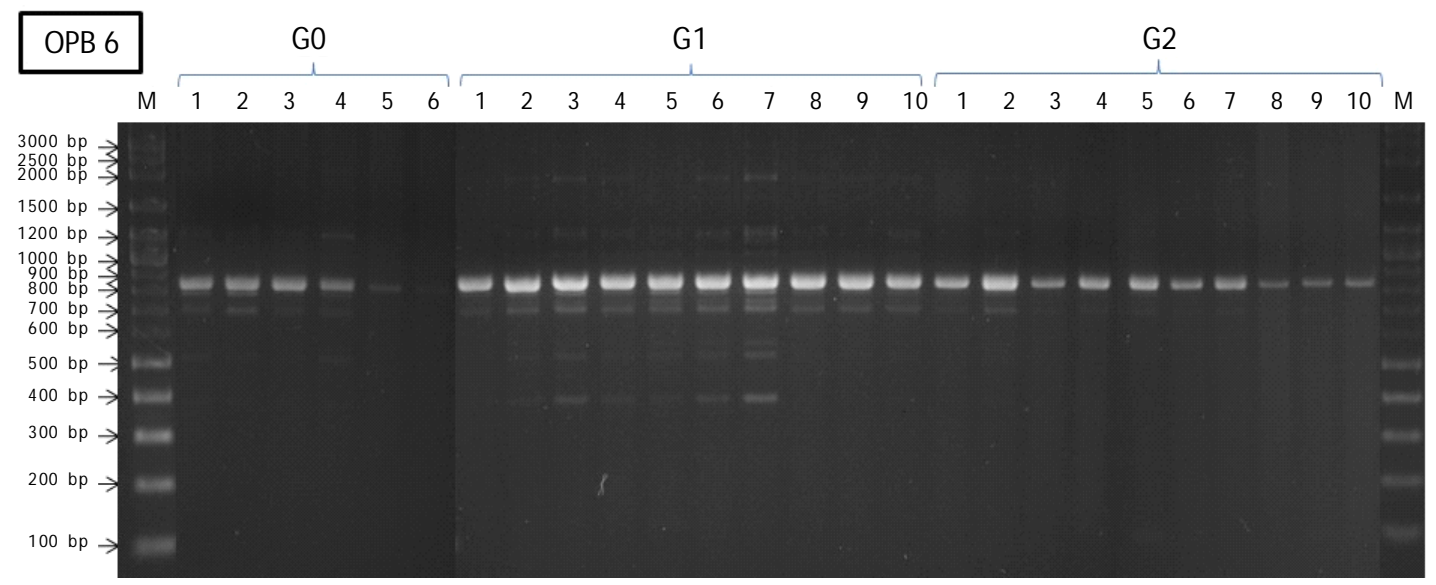

Gambar 4. Profil fragmen RAPD hasil amplifikasi DNA dari tiga generasi ikan cupang Betta rubra menggunakan primer OPB-06.

Figure 4. RAPD fragment profiles of DNA amplification result of the three generations of Betta rubra using primer OPB-06.

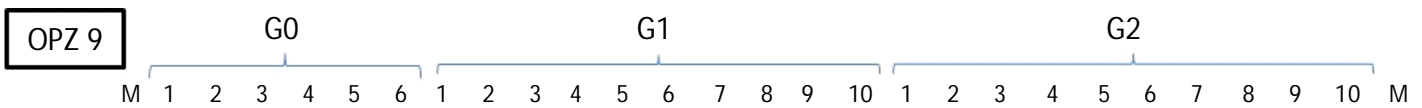

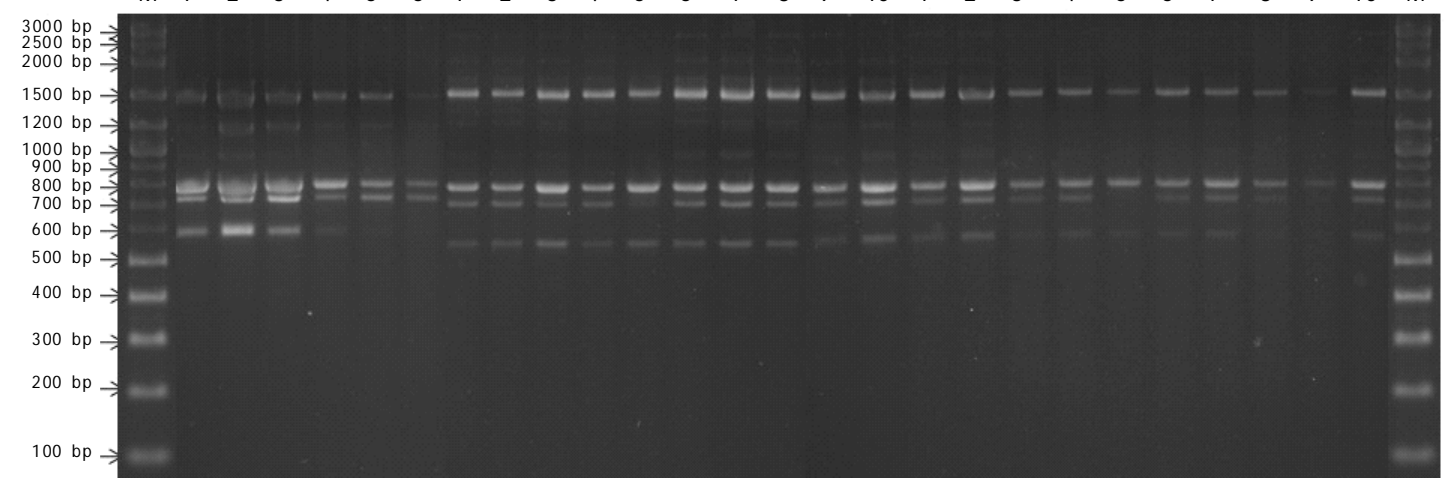

Gambar 5. Profil fragmen RAPD hasil amplifikasi DNA dari tiga generasi ikan cupang Betta rubra menggunakan primer OPZ-09.

Figure 5. RAPD fragment profiles of DNA amplification result of the three generations of Bettarubra using primer OPZ-09. 


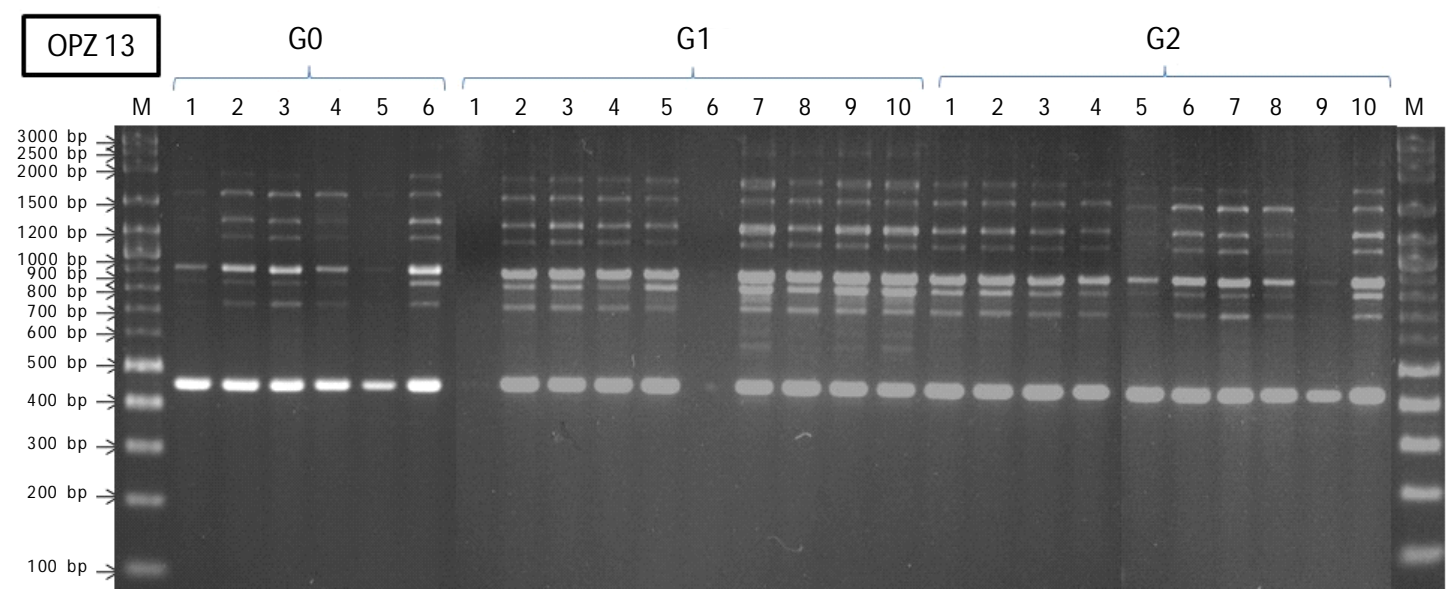

Gambar 6. Profil fragmen RAPD hasil amplifikasi DNA dari tiga generasi ikan cupang Betta rubra menggunakan primer OPZ 13.

Figure 6. RAPD fragment profiles of DNA amplification result of the three generations of Betta rubra using primer OPZ-13.

Tabel 3. Kisaran jumlah dan ukuran fragmen pada tiap populasi per primer, serta jumlah lokus per primer

Table 3. Range of number of occurrences of fragments per population per primer and number of loci per primer

\begin{tabular}{ccccc}
\hline Populasi (Population) & Kisaran (Range) & OPZ-9 & OPB-6 & OPZ-13 \\
\hline \multirow{2}{*}{ G-0 } & Jumlah fragmen (Number of fragments) & $5-6$ & $1-5$ & $3-10$ \\
\cline { 2 - 5 } & Ukuran fragmen (Fragment size) & $500-1,500$ & $500-1,200$ & $400-2,600$ \\
\hline \multirow{2}{*}{ G-1 } & Jumlah fragmen (Number of fragments) & $8-9$ & $2-9$ & $4-10$ \\
\cline { 2 - 5 } & Ukuran fragmen (Fragment size) & $500-2,800$ & $300-2,000$ & $400-2,600$ \\
\hline \multirow{2}{*}{ G-2 } & Jumlah fragmen (Number of fragments) & $2-9$ & $1-9$ & $3-9$ \\
\cline { 2 - 5 } & Ukuran fragmen (Fragment size) & $500-2,800$ & $700-1,900$ & $400-1,900$ \\
\hline \multirow{2}{*}{ Total } & Jumlah fragmen (Number of fragments) & $2-9$ & $1-9$ & $3-10$ \\
\cline { 2 - 5 } & Ukuran fragmen (Fragment size) & $500-2,800$ & $300-2,000$ & $400-2,600$ \\
\hline & Jumlah lokus (Number of loci) & $\mathbf{1 0}$ & $\mathbf{1 1}$ & $\mathbf{1 3}$ \\
\hline
\end{tabular}

Tabel 4. Nilai heterozigositas dan polimorfisme tiga populasi ikan Betta rubra Table 4. The value of heterozygo sity and polymorphism three fish populations of Betta rubra

\begin{tabular}{cccc}
\hline $\begin{array}{c}\text { Populasi } \\
\text { Population }\end{array}$ & $\begin{array}{c}\text { Heterozigositas } \\
\text { Heterozygosity }\end{array}$ & $\begin{array}{c}\text { Polimorfisme } \\
\text { Polymorphism } \%\end{array}$ & $\begin{array}{c}\text { Jumlah sampel } \\
\text { Number of samples }\end{array}$ \\
\hline G-0 & 0.1782 & 47.06 & 6 \\
G-1 & 0.2421 & 64.71 & 10 \\
G-2 & 0.1577 & 44.12 & 10 \\
Seluruh populasi & 0.255 & 76.47 & 26 \\
Total population & & & \\
\hline
\end{tabular}


polimorfisme tertinggi adalah pada populasi G-1 $(64,71 \%)$ dan terendah juga pada populasi G-2 $(44,12 \%)$. Pada populasi tetua yaitu G-0 memiliki nilai heterozigositas 0,1782 dan nilai polimorfisme $47,06 \%$ dengan nilai yang hampir mendekati populasi G-2. Keragaman genetik dari generasi G-0 Betta rubra meningkat pada generasi G-1. Peningkatan yang terjadi dipengaruhi beberapa faktor. Pertama, jumlah sampel yang dianalisis lebih sedikit dari jumlah induk yang digunakan dalam perkawinan untuk menghasilkan keturunan G-1. Hal ini berdampak pada tidak terbacanya beberapa alel pada data genotipe induk (G$0)$, sementara pada data genotipe G-1 terjadi penambahan alel dari sumber genetik induk yang tidak ikut dianalisis. Kedua, pemijahan yang dilakukan pada ikan Betta rubra meskipun dilakukan secara massal, namun keturunan yang dihasilkan merupakan anakan dari sepasang induk jantan dan betina dalam satu siklus pemijahan, karena sifat memijah ikan Betta rubra secara mouthbrooder tidak mudah berganti pasangan saat pemijahan berlangsung. Hal ini dapat meningkatkan variasi genetik yang dihasilkan ke keturunan selanjutnya yang terlihat dari nilai heterozigositas yang meningkat. Menurut DupontNivet et al. (2006), perbedaan desain perkawinan menghasilkan variabilitas genetik jangka panjang dan respons genetik.

Pada populasi G-2 keragaman genetik menurun drastis dibandingkan kedua generasi sebelumnya. Hal ini diduga makin minimnya sumber genetik yang diturunkan dari hasil pemijahan generasi G-1. Menurut Nugroho et al. (2016), keterbatasan migrasi secara alami dapat menurunkan keragaman genetik. Umumnya ikan yang dibudidayakan pola migrasinya sudah dibatasi dengan wadah pemeliharaan. Selain itu, sumber genetik yang digunakan terbatas sehingga potensi inbreeding bisa terjadi. Keragaman genetik yang menurun akibat pola migrasi yang lebih sempit terjadi pada ikan gurami dari berbagai strain pada heterozigositas dengan kisaran 0,0203-0,1735 (Nugroho et al., 2016), ikan tengadak memiliki heterozigositas dengan kisaran 0,09-0,18 (Radona et al., 2016), pada ikan mas rajadanu 0,12-0,20 (Cahyanti et al., 2014), dan pada ikan uceng memiliki kisaran nilai heterozigozitas 0,075-0,153 (Ath-thar et al., 2018). Berbeda dengan ikan hias rainbow Kurumoi hasil budidaya yang memiliki keragaman genetik yang tinggi dengan nilai heterozigositas yang tinggi, yaitu berkisar 0,2091-0,2479 (Hayuningtyas et al., 2016) dan pada ikan belida budidaya keragaman genetiknya juga tinggi yaitu 0,2922-0,2978 (Nugroho et al., 2019).

Jarak genetik antar tiga populasi ikan Betta rubra berdasarkan jarak modifikasi Roger's (Wrigth, 1978) dalam (Miller, 1997) menunjukkan bahwa antara populasi G-0 dan G-2 lebih dekat dibanding G-0 dengan G-1 maupun hubungan antara G-1 dengan G2. Sehingga performa genotipe ikan Betta rubra G-0 memiliki kemiripan yang lebih dekat dengan G-2 dibanding G-1. Hubungan kekerabatan antar tiga populasi Betta rubra ditampilkan pada dendogram Gambar 7.

Secara keseluruhan ikan Betta rubra generasi tetua yaitu G-0 telah menghasilkan generasi G-1 yang memiliki keragaman genetik yang tinggi dengan nilai heterozigositas yang tinggi dan polimorfisme yang tinggi juga. Namun pada generasi selanjutnya yaitu G-2 terjadi penurunan kualitas genetik dengan nilai heterozigositas dan derajat polimorfisme yang lebih rendah dibandingkan populasi G-1 maupun populasi G-0. Hal ini mengindikasikan bahwa sampel yang dianalisis merupakan dari sumber genetik yang sama sehingga data hasil analisisnya cenderung lebih homogen. Kualitas genetik yang menurun dari generasi G-1 ke G-2 mengindikasikan terjadinya inbreeding atau silang dalam di antara sesama generasi G-1. Menurut Asih et al. (2008), inbreeding dapat terjadi karena kondisi lingkungan perairan dan pola migrasi yang terbatas. Ikan Betta rubra yang dibudidayakan di BRBIH pada wadah styrofoam $40 \mathrm{~cm} \times 60 \mathrm{~cm} \times 40 \mathrm{~cm}$, dengan tempat yang terbatas; dipelihara bersama untuk meminimalisir gerak dan meningkatkan potensi inbreeding.

Pada Gambar 7 ditampilkan dendogram yang merupakan hubungan kekerabatan antara tiga generasi ikan cupang alam B. rubra. Hubungan kekerabatan di

Tabel 5. Jarak genetik tiga populasi ikan Betta rubra berdasarkan jarak modifikasi Roger's (Wright, 1978) dalam (Miller, 1997)

Table 5. Genetic distance of the three Betta rubra populations based on a modified Roger's distance (Wright, 1978) in (Miller, 1997)

\begin{tabular}{|c|c|c|c|}
\hline & G-0 & G-1 & G-2 \\
\hline $\mathrm{G}-0$ & * * w w & & \\
\hline G-1 & 0.3225 & * & \\
\hline $\mathrm{G}-2$ & 0.2415 & 0.3559 & 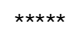 \\
\hline
\end{tabular}



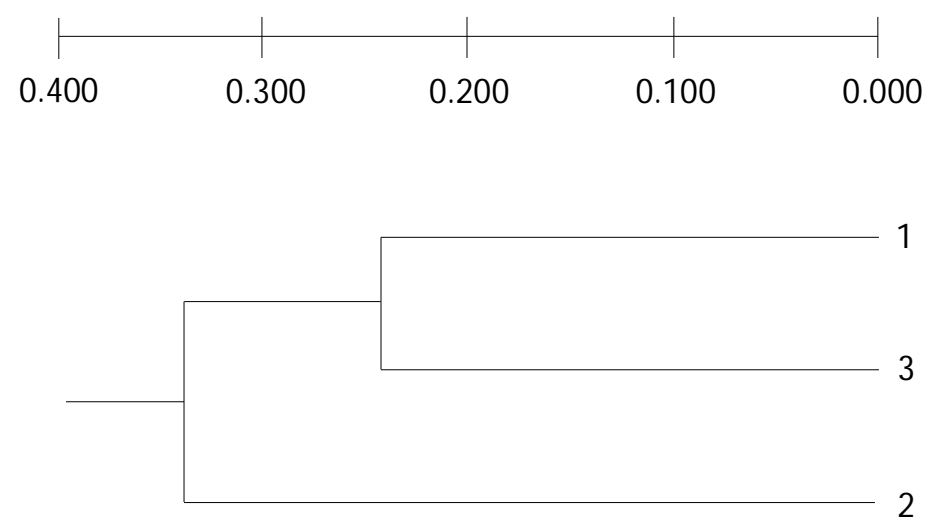

Gambar 7. Dendogram hubungan kekerabatan antara tiga populasi ikan Betta rubra (Keterangan: 1= G-0, 2= G-1, dan 3= G-2).

Figure 7. Dendogram of genetic relationship between threegenerations of Betta rubra (Note: $1=\mathrm{G}-0,2=\mathrm{G}-1$, and $3=\mathrm{G}-2$ ).

Tabel 6. Hasil uji FST berpasangan terhadap tiga generasi ikan Betta rubra Table 6. FST test result paired with three generations of Betta rubra

\begin{tabular}{|c|c|c|c|}
\hline & G-0 & G-1 & G-2 \\
\hline G-0 & 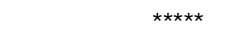 & & \\
\hline G-1 & $0.0208^{s}$ & * w & \\
\hline G-2 & $0.0844^{\mathrm{ns}}$ & $0.0003^{s}$ & *tw $4 *$ \\
\hline Keterangan (Note): & $\begin{aligned} \mathrm{S}= & \text { berbeda nyata } \\
& \text { significantly } \mathrm{d} \\
\mathrm{NS}= & \text { tidak berbeda } \\
& \text { not significan }\end{aligned}$ & $\begin{array}{l}\text { alpha }(\mathrm{P}<0 \\
\text { the signific } \\
\text { taraf alpha } \\
\text { at the sigr }\end{array}$ & $\begin{array}{l}<0.05) \\
P(P>0.05)\end{array}$ \\
\hline
\end{tabular}

antara tiga generasi ikan cupang alam ini membentuk dua cluster yaitu populasi G-0 dengan G-2 sementara G-1 berada di luar cluster. Berdasarkan hasil uji FST berpasangan terhadap tiga generasi ikan Betta rubra nilai keragaman genetik dan hubungan kekerabatan antara populasi G-0 dengan populasi G-1 berbeda nyata. Sama halnya dengan hubungan antara populasi G-1 dengan G-2 juga berbeda nyata. Namun antara G2 dengan G-0 nilai keragaman genetiknya menjadi lebih menyerupai dan hubungan kekerabatannya lebih dekat sehingga tidak berbeda nyata di antara keduanya bahkan lebih rendah dibandingkan G-0. Hal ini mengindikasikan bahwa inbreeding yang terjadi pada G-2 menghasilkan performa genetik yang lebih rendah dibandingkan tetuanya yaitu G-0.

Secara fenotipe melalui hasil pengukuran truss morfometrik diperoleh hasil rasio antara pengukuran panjang karakter truss dengan panjang standar. Pada beberapa karakter di bagian kepala dan pangkal ekor memiliki karakter pembeda secara fenotipe terhadap tiga generasi ikan B. rubra (Tabel 8). Perbedaan karakter antar populasi yang masih satu spesies terjadi akibat pola adaptasi ikan terhadap lingkungan. Salah satu bentuk adaptasi ikan adalah perubahan bentuk tubuh dan ukuran beberapa bagian tubuh (Wijayanti et al., 2017).

Keragaman genetik secara fenotipe juga dapat dilihat dari nilai koefisien keragaman yang ditampilkan pada Tabel 9. Koefisien keragaman pada populasi G-0 memiliki rataan $7,62 \%$ dengan kisaran variasi $3,41 \%$ 20,67\% Populasi G-1 memiliki nilai rataan koefisien keragaman $10,71 \%$ dengan kisaran $6,08 \% 21,84 \%$ Sementara pada populasi G-2 nilai koefisiensi keragaman memiliki rataan 9,01\% dengan kisaran 3,54\%19,05\% Sehingga hasil koefisiensi keragaman G-0 lebih rendah dibanding populasi G-1 dan G-2. Kisaran keragaman pada ikan Betta rubra ini lebih rendah dibandingkan ikan gabus yang didomestikasi dari Kalimantan koefisien keragaman berkisar 2,383\% $22,104 \%$ (Kusmini et al., 2015). Terjadi peningkatan 
Variasi genetik tiga generasi ikan hias cupang alam endemik ..... (Erma Primanita Hayuningtyas)

Tabel 7. Nilai rata-rata karakter truss morfometrik dari tiga generasi ikan cupang Betta rubra Table 7. Average values of truss morphometric character of the three generations of Betta rubra

\begin{tabular}{|c|c|c|c|c|c|}
\hline \multicolumn{2}{|c|}{ Karakter morfometrik } & G-0 & G-1 & G-2 & \multirow{2}{*}{$\frac{\text { Sig }}{0.002^{S}}$} \\
\hline & Al & $0.14 \pm 0.01$ & $0.16 \pm 0.02$ & $0.13 \pm 0.01$ & \\
\hline & A2 & $0.22 \pm 0.01$ & $0.24 \pm 0.03$ & $0.26 \pm 0.02$ & $0.01^{S}$ \\
\hline Kepala & A3 & $0.36 \pm 0.01$ & $0.39 \pm 0.03$ & $0.38 \pm 0.03$ & 0.202 \\
\hline \multirow[t]{4}{*}{ Head } & A4 & $0.27 \pm 0.02$ & $0.28 \pm 0.02$ & $0.28 \pm 0.02$ & 0.574 \\
\hline & A5 & $0.34 \pm 0.04$ & $0.39 \pm 0.03$ & $0.39 \pm 0.02$ & $0.008^{S}$ \\
\hline & A6 & $0.31 \pm 0.04$ & $0.31 \pm 0.02$ & $0.30 \pm 0.03$ & 0.619 \\
\hline & B1 & $0.14 \pm 0.02$ & $0.15 \pm 0.03$ & $0.16 \pm 0.03$ & 0.313 \\
\hline \multirow{4}{*}{$\begin{array}{l}\text { Badan tengah } \\
\text { Middle body }\end{array}$} & B3 & $0.32 \pm 0.02$ & $0.33 \pm 0.04$ & $0.32 \pm 0.02$ & 0.779 \\
\hline & B4 & $0.32 \pm 0.02$ & $0.33 \pm 0.03$ & $0.31 \pm 0.02$ & 0.121 \\
\hline & B5 & $0.42 \pm 0.02$ & $0.43 \pm 0.03$ & $0.42 \pm 0.01$ & 0.58 \\
\hline & B6 & $0.30 \pm 0.01$ & $0.31 \pm 0.02$ & $0.32 \pm 0.02$ & 0.202 \\
\hline \multirow{5}{*}{$\begin{array}{l}\text { Badan belakang } \\
\text { Rear body }\end{array}$} & $\mathrm{Cl}$ & $0.47 \pm 0.04$ & $0.50 \pm 0.03$ & $0.47 \pm 0.04$ & 0.287 \\
\hline & C3 & $0.12 \pm 0.00$ & $0.13 \pm 0.02$ & $0.13 \pm 0.02$ & 0.729 \\
\hline & C4 & $0.26 \pm 0.02$ & $0.26 \pm 0.02$ & $0.26 \pm 0.02$ & 0.757 \\
\hline & C5 & $0.36 \pm 0.02$ & $0.38 \pm 0.03$ & $0.38 \pm 0.02$ & 0.454 \\
\hline & $\mathrm{C} 6$ & $0.38 \pm 0.02$ & $0.40 \pm 0.04$ & $0.38 \pm 0.02$ & 0.35 \\
\hline \multirow{5}{*}{$\begin{array}{l}\text { Pangkal ekor } \\
\text { Tail }\end{array}$} & D1 & $0.03 \pm 0.01$ & $0.04 \pm 0.01$ & $0.05 \pm 0.01$ & 0.019 \\
\hline & D3 & $0.21 \pm 0.02$ & $0.22 \pm 0.03$ & $0.21 \pm 0.02$ & 0.964 \\
\hline & D4 & $0.14 \pm 0.01$ & $0.14 \pm 0.02$ & $0.14 \pm 0.01$ & 0.945 \\
\hline & D5 & $0.57 \pm 0.03$ & $0.51 \pm 0.05$ & $0.47 \pm 0.04$ & $0.001^{\mathrm{S}}$ \\
\hline & D6 & $0.32 \pm 0.02$ & $0.28 \pm 0.03$ & $0.27 \pm 0.02$ & $0.003^{S}$ \\
\hline \multicolumn{2}{|c|}{ Panjang standar (Standard length ) } & $5.43 \pm 0.24$ & $4.69 \pm 0.20$ & $4.34 \pm 0.21$ & \\
\hline
\end{tabular}

Keterangan (Description): $S=$ berbeda nyata $(P<0,05)$ (Significantly different $(P<0.05))$

Tabel 8. Koefisien keragaman (CV) dari 21 karakter truss morfometrik dari tiga generasi ikan cupang Betta rubra

Table 8. Coefficient of variation (CV) from 21 truss morphometric character of the three generations of Betta rubra

\begin{tabular}{|c|c|c|c|c|}
\hline \multicolumn{2}{|c|}{ Karakter morfometrik } & \multirow{2}{*}{\begin{tabular}{|l} 
G-0 \\
7,53
\end{tabular}} & \multirow{2}{*}{$\begin{array}{c}\text { G-1 } \\
14,95\end{array}$} & \multirow{2}{*}{\begin{tabular}{|c|}
$\mathbf{G}-\mathbf{2}$ \\
11,63
\end{tabular}} \\
\hline & $\overline{A 1}$ & & & \\
\hline & $\mathrm{A} 2$ & 4,77 & 11,68 & 8,02 \\
\hline Kepala & A3 & 3,75 & 8,62 & 8,25 \\
\hline Head & A4 & 7,75 & 6,34 & 7,79 \\
\hline & A5 & 10,36 & 8,35 & 5,57 \\
\hline & A6 & 11,53 & 6,11 & 8,82 \\
\hline \multicolumn{2}{|c|}{ Rata-rata (Average) } & 7,61 & 9,34 & 8,35 \\
\hline \multirow{5}{*}{$\begin{array}{l}\text { Badan tengah } \\
\text { Middle body }\end{array}$} & B1 & 11,20 & 19,85 & 18,12 \\
\hline & B3 & 6,97 & 12,13 & 6,70 \\
\hline & B4 & 7,35 & 7,88 & 5,75 \\
\hline & B5 & 4,95 & 7,99 & 3,54 \\
\hline & B6 & 3,41 & 7,76 & 6,46 \\
\hline \multicolumn{2}{|c|}{ Rata-rata (Average) } & 6,77 & 11,12 & 8,11 \\
\hline \multirow{5}{*}{$\begin{array}{l}\text { Badan belakang } \\
\text { Rear body }\end{array}$} & $\mathrm{C} 1$ & 8,20 & 6,08 & 8,05 \\
\hline & C3 & 3,56 & 18,74 & 19,05 \\
\hline & C4 & 7,98 & 6,28 & 8,63 \\
\hline & $\mathrm{C} 5$ & 6,11 & 6,97 & 5,92 \\
\hline & $\mathrm{C} 6$ & 5,93 & 9,24 & 5,04 \\
\hline \multicolumn{2}{|c|}{ Rata-rata (Average) } & 6,36 & 9,46 & 9,34 \\
\hline \multirow{5}{*}{$\begin{array}{l}\text { Pangkal ekor } \\
\text { Tail }\end{array}$} & D1 & 20,67 & 21,84 & 18,80 \\
\hline & D3 & 8,57 & 11,81 & 9,48 \\
\hline & D4 & 7,98 & 11,61 & 6,24 \\
\hline & D5 & 4,76 & 9,49 & 8,89 \\
\hline & D6 & 6,71 & 11,28 & 8,51 \\
\hline \multicolumn{2}{|c|}{ Ratarata (Average) } & 9,74 & 13,21 & 10,39 \\
\hline \multicolumn{2}{|c|}{ Rataan keseluruhan (Total average ) } & 7,62 & 10,71 & 9,01 \\
\hline
\end{tabular}


keragaman dari populasi G-0 ke populasi G-1, namun terjadi penurunan keragaman dari populasi G-1 ke G2. Dari hasil analisis secara fenotipe diperoleh pola yang serupa dengan hasil analisis secara genotipe. Menurut Susanto (2011), faktor genetik dan faktor lingkungan jarang sekali berdiri sendiri-sendiri dalam memengaruhi suatu fenotipe. Adanya interaksi dan asosiasi dapat memengaruhi antar faktor. Asosiasi antara faktor lingkungan dan faktor genetik dapat meningkatkan maupun menurunkan nilai fenotipe. Karakter truss morfometrik dipengaruhi oleh lingkungan, penjumlahan keragaman genetik, dan interaksi antara lingkungan dan genetik (Susanto, 2011).

\section{KESIMPULAN}

Hubungan kekerabatan di antara tiga generasi ikan cupang ini membentuk dua cluster yaitu populasi G-0 dengan G-2 sementara G-1 berada di luar cluster. Keragaman genetik ikan Betta rubra G-0 dan G-1 memiliki perbedaan yang sangat nyata $(P<0,05)$, sedangkan antara G-0 dan G-2 tidak berbeda nyata $(P>0,05)$. Pada populasi G-2 terjadi penurunan kualitas genetik yang ditandai dengan menurunnya nilai heterozigositas dari 0,2421 menjadi 0,1577. Penurunan kualitas genetik yang terjadi pada generasi G-2 diduga karena adanya inbreeding atau silang dalam. Keragaman genetik pada tiga generasi Betta rubra memiliki pola yang sama baik secara fenotipe maupun genotipe.

\section{UCAPAN TERIMA KASIH}

Kegiatan ini didanai oleh DIPA Tahun Anggaran 2018 Balai Riset Budidaya Ikan Hias, Kementerian Kelautan dan Perikanan. Ucapan terima kasih diucapkan kepada Nadia Mega Ariyani dan Ekki Ilham Romadona selaku analis Laboratorium Uji Genetika dan Bioteknologi, Balai Riset Budidaya Ikan Hias (BRBIH) yang terlibat dalam penelitian ini.

\section{DAFTAR ACUAN}

Arifin, O.Z., Imron, Aseppendi, Hendri, A., Mulsim, N., \& Yani, A. (2017). Hibridisasi intraspesifik antar dua populasi ikan gurami Galunggung (Osphronemus gourami, Lacepede, 1801). Jurnal Riset Akuakultur, 12(4), 315-323. http://dx.doi.org/ 10.15578/jra.12.4.2017.315-323.

Ariyanto, D., Listiyowati, N., \& Imron. (2011). Analisis truss morfometrik beberapa varietas ikan nila (Oreochromis niloticus). Jurnal Riset Akuakultur, 6(2), 187-196. http://dx.doi.org/10.15578/jra.12.4.2017. 315-323.
Asiah, N., Junianto, Yustiati, A., \& Sukendi. (2018). Morfometrik dan meristik ikan kelabau (Osteochilus melanopleurus) dari Sungai Kampar, Provinsi Riau. Jurnal Perikanan dan Kelautan, 23(1), 47-56.

Asih, S., Nugroho E., Kristanto A.H., \& Mulyasari. (2008). Penentuan genetik ikan Batak (Tor soro) dari Sumatera Utara dan Jawa Barat dengan metode analisis random amplified polymorphism DNA (RAPD). Jurnal Riset Akuakultur, 3(1), 91-97. http:/ /dx.doi.org/10.15578/jra.3.1.2008.91-97.

Ath-thar, M.H.F., Ambarwati, A., Soelistyowati, D.T., \& Kristanto A.H. (2018). Keragaan genotipe dan fenotipe ikan uceng Nemacheilus fasciatus (Valenciennes, 1846) asal Bogor, Temanggung, dan Blitar. Jurnal Riset Akuakultur, 13(1), 1-10. http:// dx.doi.org/10.15578/jra.13.1.2018.1-10.

Brezky, V.J. \& Doyle R.W. (1988). A morphometric criterian for sex discrimination in Tilapia. In Pullin, R.S.V., Bhukaswan, T., Tonguthai, K., \& Maclean, J.L. (Eds.). The Second International Symposium on Tilapia in Aquaculture. ICLARM Conference Proceedings 15. Philippines: Department of Fisheris, Bangkok, Thailand \& International Center for Living Aquatic Resources Management, Manila.

Cahyanti, W., Radona, D., Arifin, 0.Z., \& Asih, S. (2014). Analisis keragaman genetik empat populasi ikan mas Rajadanu dengan menggunakan meto de RAPD (Random Amplified Polymorphism DNA). Prosiding Forum Inovasi Teknologi Akuakultur 2014, hlm. 859-865.

Dupont-Nivet, M., Vandeputte, M., Haffray, P., \& Chevassus, B. (2006). Effect of different mating designs on inbreeding, genetic variance and response to selection when applying individual selection in fish breeding programs. Aquaculture, 252(2-4), 161-170.

Hayuningtyas, E.P. \& Kadarini, T., (2016). Keragaman genotipe tiga generasi ikan rainbow Kurumoi (Melanotaenia parva) hasil domestikasi berdasarkan RAPD. Jurnal Riset Akuakultur, 11(2), 107-114. http://dx.doi.org/10.15578/jra.11.2. 2016.107-114.

Hayuningtyas, E. P., Sinansari, S., Kusrini, E., Fahmi, M.R., \& Nur, B. (2018). Karakter genotipe tiga populasi ikan rainbow Ajamaru (Melanotaenia ajamaruensis) dari alam dan budidaya menggunakan RAPD. Jurnal Riset Akuakultur, 13(2), 105-113. http://dx.doi.org/10.15578/jra.13.2. 2018.105-113. 
Jitunews. (2015). Betta rubra, cupang alam nan cantik dari perairan Aceh. Jitunews.com, 26 Februari 2015. Diakses 6 Februari 2019 https:// m.jitunews.com/read/9967/betta-rubra-cupangalam-nan-cantik-dari-perairan-aceh.

Kusmini, I.I., Prakoso, V.A., \& Kusdiarti. (2015). Keragaman fenotipe Truss Morfometrik dan Genotipe Ikan Gabus (Channa striata) Dari Jawa Barat, Sumatera Selatan, dan Kalimantan Tengah. Jurnal Riset Akuakultur, 10(4), 501-599.

Kusmini, I.I., Gustiano, R., Radona, D., Prakoso, V.A., Putri, F.P., \& Prihadi, T.H. (2016). Karakterisasi fenotipe dan genotipe tiga populasi ikan tengadak Barbonymus schwanenfeldii. Jurnal Riset Akuakultur, 11(3), 207-216. http://dx.doi.org/ 10.15578/jra.11.3.2016.207-216.

Kristanto, A.H., Subagja, J., Cahyanti, W., \& Arifin, O.Z. (2017). Evaluasi variasi fenotipe dan genotipe populasi ikan tambakan dari Kalimantan Tengah, Jawa Barat, dan Jambi, dengan truss morfometrik dan randomly amplified polymorphic DNA (RAPD). Jurnal Riset Akuakultur, 12(3), 203-211. http:// dx.doi.org/10.15578/jra.12.3.2017.203-211.

Lante, S., Tenriulo, A., \& Palinggi, N.N. (2012). Variasi genetik ikan baronang (Siganus gutatus) asal perairan Barru, Lampung, dan Sorong menggunakan penanda RAPD (Random Amplified Polymorfism DNA). Jurnal Riset Akuakultur, 7(2), 195-204.http:/ /dx.doi.org/10.15578/jra.7.2.2012.195-204.

Miller, M.P. (1997). Tools for po pulation genetic analyses (TFPGA). (Version 1.3) USA: Northern Arizona University.
Nugroho, E., Azrita, Syandri, H., \& Refilza. (2016). Evaluasi keragaman genetik ikan Kalui (Osphronemus gouramy) dari Kabupaten Lima Puluh Kota, Sumatera Barat berdasarkan marka random amplified polymorphism DNA (RAPD). Jurnal Riset Akuakultur, 11(4), 313-319. http:// dx.doi.org/10.15578/jra.11.4.2016.313-319.

Nugroho, E., Dewi, R.R.S.P.S., Subagja, J., \& Priono, B. (2019). Keragaman genetik dan karakter biometrik ikan belida (Chitala lopis, Bleeker 1851) budidaya asal Sungai Kampar, Riau. Jurnal Riset Akuakultur, 14(1), 1-8. http://dx.doi.org/10.15578/ jra.14.1.2019.1-8.

Radona, D., Soelistyowati, D.T., Gustiano, R., Carman, O., Kusmini, I.I., \& Sundari, S. (2016). Ragam genotipe ikan tengadak, Barbonymus schwanenfeldii (Bleeker 1854) persilangan populasi Jawa dan Kalimantan berdasarkan RAPD. Jurnal Riset Akuakultur, 11(2), 99-105. http://dx.doi.org/ 10.15578/jra.11.2.2016.99-105.

Schindler, I. \& Voort, S.V.D. (2011). Re-description of Betta rubra Perugia, 1893 (Teleostei: Osphronemidae), an enigmatic fighting fish from Sumatra. Buletin of Fish Biology, 13(1), 21-32.

Susanto, A.H. (2011). Genetika. Graha IImu, 382 hlm. Wijayanti, T., Suryaningsih, S., \& Sukmaningrum, S. (2017). Analisis karakter truss morphometrics pada ikan kemprit (llisha megalopteran Swainson, 1839) Familia Pristigasteridae. Scripta Biologica, 4(2), 109-112. 